\title{
Guardianship or "Permanent Placement" of Children
}

\author{
Hasseltine B. Taylor*
}

$\mathrm{T}$ HOUSANDS OF CHILDREN are separated from their parents and living for long periods of time in foster care, in group homes, or in institutions. ${ }^{1}$ Many of them are not free for adoption or have no adoptive parents in prospect. The need of many of them for permanent or long-term foster care has been pointed out. ${ }^{2}$ For some of these children the formal and personal relationship of guardian and ward is believed by this writer to be appropriate not only from a legal standpoint but from a social standpoint as well. Sucli a status could contribute much to their emotional security and their identity in the home and the community. ${ }^{3}$ The institution of guardian and ward is well established in legal history."

The parents of some "children in need of parents" may be unwilling to consent to their adoption. Yet their children have not been so completely abandoned or so seriously neglected as to be freed for adoption without their consent. Other parents may have delayed in reaching a decision to give the children in adoption until the children are too old to be in demand or to accept strangers easily in the place of parents. Some children are handicapped in ways that make licensed agencies hesitate to recommend them for adoption. Some are children belonging to minority groups in which hittle tradition of formal adoption exists. Despite the need for permanent homes many such children continue to live under temporary and unsatisfactory arrangements when they need and hunger for responsible, intimate, and durable relationships.

These children are receiving substitute care in various ways. Some are in the homes of relatives where the relatives, the parents, voluntary or governmental agencies support them. Others have been placed in foster homes selected and supervised by licensed child welfare agencies. In

*A.B., 1926, Louisiana State University; M.A., 1927, Columbia University; Ph.D., 1934, J.D., 1939, University of Chicago. Lecturer, University of California School of Social Welfare, Berkeley.

I Jetre, Chumpen, Problems and Services in Child Welfare Programs 76 (1963). The estimated number in tenporary and long-term foster care rose between 1958 through March 1961 from 229,500 to 255,000. Kahn, Child Welfare: Trends and Directions, 41 Camb WELFARE 459, 464 (1962).

2 Smith, Permanenit or Long-Term Foster Family Care, 43 Chul Werfare 192 (1964).

8 Weissman, Guardianship: Every Child's Right, Annals, Sept. 1964, p. 134.

41 SchodLer, Domestic Retations 907-24 (1921); TaYLoR, Gdardian and Ward 9-30 (1934); WOERNER, THE AMIERICAN LAW OF GUARDIANSHIP 39-77 (1897).

5 Maas \& Eingler, Camidren in Need of Parents (1959). 
California, many are in foster homes and institutions receiving state and county aid.

Clild welfare agencies have made extended and organized efforts to develop foster family care and to create a demand for adoption of children but such agencies have given little attention to exploring the potential supply of legally appointable guardians or to the study of children for whom the relationship of guardian and ward might accord better with their needs than either adoption or substitute care in families, group homes, or in institutions. Permanent placement with minimum agency oversight is being suggested. ${ }^{6}$

Society supports agencies for child welfare and expects them to provide care for children whose parents cannot or will not provide it. However, the demand for care is greater than the supply. Geographical and social mobility have reduced the desire and obligation of relatives to care for children of their own blood. As more and more married women work out of the home, fewer find it possible to care for more than their own children and often need socially provided day care or other assistance in doing even that. ${ }^{7}$ Some licensed adoption agencies have had to refuse to accept relinquishments for adoption from minority group parents for want of available adoptive-applicants. A great increase in illegitimate births has swelled the supply of children whose parents often wish to give them in adoption. ${ }^{8}$ The individual child may find himself in a succession of temporary placements where he may suffer irreparable injury to his growth and development as an integrated person. Before serious crises develop in socially provicling for child care, the alternative of guardianship, if tried, might open additional homes for clildren.

Parents, while living, are both the natural and legal guardians of their children unless they have relinquished them for adoption, have lad their right to guardianship suspended by juvenile court guardianslip, have been replaced by court-appointed guardians, or have had their rights terminated by judicial decree. ${ }^{\circ}$ Parents, like strangers, must be appointed by the proper court to serve as guardians of their children's estates except where such estates are small. A court-appointed guardian of the person has the riglits and responsibilities of a parent except for the duty

${ }^{6}$ Lewis, Foster-Family Care: Has It Fulfilled Its Promise?, Annals, Sept. 1964, p. 41; Smith, supra note 2, at 192-94.

7 Barbey, The Case for Day Care, in Helping the Fammey IN URBan Socmety 89 (Delliquadri ed. 1963).

8 It is estimated that 220,600 illegitimate births occurred in the United States in 1959. U.S. Public Healtir Service, Dep't of Health, Education \& Welfare, Vitat Statistics an THE UNTTEd States 1959 3-30 (1960).

9 See generally Fiexner, Oppenhetare \& Lenroot, The Ceind, The Fammix and The Courf (U.S. Children's Bureau Pub. No. 193, 1929). 
to support the ward. ${ }^{10}$ His office is terminable by resignation, removal for cause, or by successful assertion of the superior claim which a parent might be able to make to the child's guardianship. He is subject to the control of the court which appointed him. Yet children who are without parents or estates of their own are seldom related to a responsible adult in the relationship of guardian and ward.

Since the adoption of juvenile court laws, children who are brought to the attention of these courts and found dependent, neglected, or delinquent are made wards of the juvenile court. Whether left in the custody of their parents or placed in foster homes under the supervision of probation officers, committed to licensed institutions or to agencies for fosterhome placement, they are wards of the court. Thus children whose parental guardianship or informal care does not fall conspicuously below the community's standard are not subject to court guardianship.

In recent decades attention has been called to the advantages of guardianship for minors without guardians and to the need for social services to be available to the courts in exercising jurisdiction over their appointment and more actively assuring their accountability. ${ }^{11}$ The relationship of guardian and ward does not connote economic dependency on the part of the child. In fact, because of the failure of our law to require children to have guardians by nature or by appointment, it rather suggests that the child's own parents or someone who cared about him had planned for or sought the child's guardianship when parental care was lost by death or disability. It does not suggest that the child is or ever was "nobody's child," or a "social agency's child," or a "ward of the state."

The substitute parent when holding letters of guardianship enjoys the dignity of being in law as well as in fact a substitute parent subject only to the control of the court appointing him. He is not a foster parent whose role is contingent upon continuous supervision by a child welfare agency or juvenile court probation officer. His sense of responsibility for the child is probably stronger and the child's respect for him is probably greater when their relationship is a formal and settled one. If the guardian were selected by a child welfare agency, lie would be familiar with the availability of social services when perplexed or wanting consultation. Where the child is receiving socially provided income, he, like a parent, could be held responsible for using it for the child's own needs and be as competent to report changes in the child's economic circumstances.

10 See 5 Bancroft, Probate Practice 159-239 (2d ed. 1950).

11 Taylor, Guardian and Ward (1934); Weissman, GUardianship: A Way of Futfilling Pubutc Responsibitity for CHmidren (U.S. Children, Bureau Pub. No. 330, 1949); Breckinridge \& Stanton, The Law of Guardian and Ward with Special Reference to the Children of Veterans, 17 Soctal Service Rev. 265 (1943). 
Children without parents or estates are not likely to have a change in financial situation until they can aclieve it by their own efforts. Should the unexpected occur through gift, inlieritance, or receipt of damages for negligent injury, the appointed guardian of the person might or might not be the most suitable person to serve as guardian of the estate.

The child's welfare would probably be better served by living with a person in whom guardianship is vested than by being supervised in a home where authority is uncertainly divided. ${ }^{12}$ It would be better served where the person having physical custody does not occupy a 'contingent role which may be visualized by the child and his associates as weiglited on the side of domestic service instead of parenthood. The clild could readily identify his relationship and explain the variance in surnames. ${ }^{18}$

Social agencies which would develop and encourage the use of the relationship of guardian and ward would be able to "close the case" after satisfactory placement had been achieved for appropriate children and letters of guardianship issued, as is done when an adoption decree is entered. All suspicion that an agency lias an interest in maintaining high case loads, that it does not know when to let go of supervising liomes, or that it is depriving a child of a personal guardian by sharing responsibility for the child's custody with a foster parent would be dispelled. After the guardian's appoimtment, a client relationship, if any, would be between the agency worker and the guardian, not the worker and the child. The child's needs might again bring him to the attention of a social agency or his guardian might resign or be removed and another would liave to be appointed in his place.

It is believed that many persons for many reasons would find the role of guardian more attractive than that of adoptive parent on the one hand or foster parent on the other. The relationship of parent and child created by adoption carries with it the duty to support the child. Many suitable prospective guardians may not be economically secure or have enjoyed such security long enough to deliberately want to undertake such a responsibility. Others may feel that prior commitments or obligations are all that can be met comfortably. In some cases guardianship may provide a more satisfying emotional reward for both parties than adoption which is, regardless of legal effects, still a substitute for a natural relationship. A guardian can be enabled to support his ward by socially provided income without any

\footnotetext{
12 See Wolins, Seiecting Foster Parents 15-33 (1963).

13 Glover \& Reid, Unmet and Future Needs, Annals, Sept. 1964, pp. $15-16$ states: "It is thought that many Negro families as-well as white, because of economic risks and responsibilities of adoption, will be interested in taking a young child into their homes on a permanent basis. Agencies will pay all expenses of the child's care; at the same time they will encourage the foster parents to assume as much responsibility as they are willing to take in other areas, even allowing them to give their names to the clildren."
} 
suggestion of failure on his part. Such failure is often felt by parents when they cannot support their children. Guardianship of a child old enough to remember his parents or to cherish his own identity may serve the needs of the child and do so more comfortably for both. An adoptive parent, however sensitive he may be, occupies a role differently defined by society.

What appears to be lacking for this relationship to have the potential of another viable social resource for children in need of substitute parents is: (1) the extension of socially provided and reasonably assured income maintenance for children without other sources of income to children with guardians, and (2) conviction on the part of child welfare agencies and social workers that guardianship is worthy of exploration along with the possibilities of adoption or other forms of substitute care.

For these and other reasons which might be enumerated, the writer would hike to see a demonstration project or projects undertaken by a public or voluntary child welfare agency and financed by funds authorized by section 526 of the Social Security Act as amended. ${ }^{14}$ California offers particular opportunities for undertaking such a project because its Aid to Families with Dependent Children already extends to children in foster homes and institutions. ${ }^{15}$ Such a demonstration project might supply a modicum of evidence in support of federal financial participation in state aid to needy children living with legally appointed guardians as well as children hiving with parents and specified relatives.

The Advisory Council on Public Assistance considered the extension of federal aid to the states for programs imcluding children in foster homes. ${ }^{16}$ It did not recommend this extension. Before Congress sees fit to enact such an expansion of coverage, the results of demonstration projects might influence Congress and state legislatures to make the lesser expansion-aid to needy children hiving, with legally appointed guardians.

1474 Stat. 997 (1960), as amended, 42 U.S.C. $\$ 726$ (1964). Under the Social Security Act of 1935 and its subsequent amendments federal grants-in-aid to states have been available for state programs providing money payments to dependent children living in their own homes or with specified relatives and social insurance benefits for children of primary beneficiaries have been available to many children. 70 Stat. 848 (1956), as amended, 42 U.S.C. \& 601 (1964). In the absence of a surviving parent, children's benefits from the National OASDI program are paid to representative payees selected by and accountable to the administrative agency. Guardians are not required. The amendments of 1962 authorize state programs to use "restrictive payments" in a small percentage of the recipient families without loss of federal aid. 76 Stat. 188 (1962), 42 U.S.C. \& 605 (1964). "Restrictive payments" are payments to persons other than the statutory caretaker (parent or relative) when the parent or relative caretaker demonstrates incapacity or unwillingness to use the aid for the child's needs.

15 CaL. Welfare \& INST'NS Code § 1500.1(b).

16 Advisory Council on Public Assistance, Report, S. Doc. No. 93, 86th Cong., 2d Sess. 38 (1960). 
Some states already provide for waiver of costs of guardianship proceedings where public aid is involved. ${ }^{17}$

Sucl a demonstration, if it supplied positive evidence supporting the hypothesis upon which such a proposal would be based, miglit result in greater use of Child Welfare Services by the court in appointing and supervising guardians of the persons of all children. ${ }^{18}$ It might even bring reconsideration of the use of strangers as payees for minor and incompetent beneficiaries of social insurance and for children receiving Aid to Families with Dependent Clildren whose parent cannot be trusted with the grants. The essential distinction between modern public income maintenance programs and relief under the poor laws is that administrative authority is over programs only and does not extend to power over persons. This distinction should be preserved but is threatened by payments of aid to third parties selected by administrative agencies without a judicial finding that the parent has abused the trust.

Sucl a project would not demonstrate a substitute for adoption which is clearly superior wherever it is both possible and appropriate. It would not be intended to demonstrate even the value of every child having a guardian by nature or by appointment. ${ }^{19}$ It could demonstrate with what ease or difficulty suitable persons willing to accept appointment by the court to this office could be found. It could throw light on whether a permanent home with a court appointed guardian is to be preferred to a permanent placement with minimal supervision of the placement agency. It is worth trying before there is a swing in fashion to group care. ${ }^{20}$

It may be that the great changes wrought in the structure of the family and of society and in the minds of men since the 18th Century have rendered the relationship of guardian and ward vestigial or even obsolete. Manifestations of the social interest in clildren so often advanced under the banner of the "rights of children" and projected in terms of their social importance as "human resources" grow apace. Yet there is a growing recognition that many are weary of alienation and want to embark upon "the quest for community." 21 Its stimulation is one of the purposes, or at least this is loped to be one of the consequences of the Economic Opportunity Act of 1964. We cannot say as Lord Eldon did in the Wellesley case, "It is not ... from any want of jurisdiction that it does

\footnotetext{
17 E.g., CAL. Gov'T CODE § 6102.

18 See Werssman, op. cit. supra note 11 , at 3 .

19 As recommended in SMrtr, Tre RIGHT TO. LIFE 122-152 (1955), where the use of substitute payees is roundly condemned.

20 Wolins, Political Orientation, Social Reality, and Child Welfare, 38 Soctax SERvice REV. 429 (1964).

21 NISBET, THE QUEST FOR COMnUNTTX (1953).

22 Wellesley v. Beaufort, 2 Russ. 1, 21, 38 Eng. Rep. 236, 243 (1827).
} 
not act, but from a want of means to exercise its jurisdiction ...." Today in the United States, the means are available to permit the welfare of the child, not his estate, to determine the social and legal provisions made for him. 